\title{
The Impact of Different Instructions on Vietnamese EFL Students' Acquisition of Formulaic Sequences
}

\author{
Do Thi $\mathrm{Ha}^{1}$ \\ ${ }^{1}$ Faculty of Foreign Languages, HCMC University of Technology and Education, Vietnam \\ Correspondence: Do Thi Ha, Faculty of Foreign Languages, HCMC University of Technology and Education, \\ Vietnam. E-mail: dothiha1985@gmail.com, hadt@hcmute.edu.vn
}

Received: April 17, 2017 Accepted: July 1, 2017 Online Published: July 3, 2017

doi: 10.5539/elt.v10n8p18 URL: http://doi.org/10.5539/elt.v10n8p18

\begin{abstract}
The paper explores how various teaching methods, namely Phonology-Based Instruction (PBI) and Translation-Based Instruction (TBI), have an effect on students' acquisition of formulaic sequences. 20 multiword expressions were taught to 48 Vietnamese EFL students from three intact classes as 2 treatment groups (PBI and TBI) and 1 control group. Right after completing the tasks, the three groups were tested on their ability to identify (Form Recognition) and produce (Form and Meaning Recall) the lexical phrases by an immediate post-test. A delayed test was administered two weeks later for better comparsion of their retention. The results showed that PBI and TBI groups significantly outperformed the control one on most of the test levels. Especially, TBI tended to be more effective than PBI in two cases as regards both Repeating and Non-repeating items. It is believed that if the results and the proposed suggestions of this research are taken into consideration, major improvements could occur in language teaching programs, leading to students' higher vocabulary uptake.
\end{abstract}

Keywords: EFL students, formulaic sequences, Phonology-Based Instruction (PBI), Translation-Based Instruction (TBI), Form Recognition, Form and Meaning Recall

\section{Introduction}

Research has shown the relevance of formulaic sequences (i.e. multiword units that native speakers prefer to use) to second/foreign language learners (Wray, 2002; Schmitt, 2004; Lindstromberg \& Boers, 2008a; Wood, 2010). Estimates vary, but Hill (2000) stated that such building blocks are found in "up to $70 \%$ of everything we say, hear, read, or write" (p. 53). As the ubiquity and importance of these expressions have been acknowledged, there arises a problem of whether L2 learners should be given explicit or incidental vocabulary learning opportunities.

According to Craik and Lockhart (1972), the chance that new information will be stored in long-term memory does not depend on the length of time that it is stored in short-term memory but rather on the depth with which it is firstly processed. Smith (1991) also suggested that changing the quality of input can stimulate learners' processing of linguistic material. Teachers' responsibility is to choose suitable items and equip learners with powerful strategies so that they get the most benefit of what they have learned inside and outside classroom (Lewis, 2000).

On the one hand, students' noticing of phonological repetition has been proved to promote more retention of lexical phrases (Lindstromberg \& Boers, 2008a \& 2008b). On the other hand, translation has been advocated in engaging students' elaborate processing of the target words (Watanabe, 1997; Laufer \& Girsai, 2008). However, there has not been much research on the effectiveness of these two instruction types. This study will, therefore, investigate learning gains at both receptive (recognition) and productive (recall) levels when students engage in form and meaning-oriented activities.

\section{Literature Review}

\subsection{Formulaic Sequences (FS) and L2 Learners' Acquisition of FS}

The set word strings which thrive in a language have been labelled variously as lexical phrases, multiword items/units, formulaic sequences, fixed expressions, prefabricated chunks, idioms, collocations, lexical bundles, conventional sequences, to name but a few (Wray, 2002; Forsberg, 2010; Tremblay, Derwing, Libben, \& Westbury, 2011). The following definition by Wray (2000) has conveyed their holistic nature as: 
A sequence, continuous or discontinuous, of words or other meaning elements, which is or appears to be, prefabricated: that is, stored and retrieved whole from memory at the time of use, rather than being subject to generation or analysis by the language grammar. (p. 465)

According to Nattinger and DeCarrico's (1992) classification, there are four large classes of lexical items. Polywords (e.g. the day after tomorrow, in a flash) are fixed expressions that have to be understood as single units. Institutionalized expressions are sentence-length and invariable, which can stand alone as utterances such as how do you do, long time no see. Phrasal constraints, however, allow alterations of lexical and phrase categories, as in a day ago, a year ago, a very long time ago. Sentence builders provide a framework to make full sentences, so they are open to lots of variation and addition. Examples include I think that X, there is no doubt that X, not only X...but also Y.

Chunk mastery has been considered a prerequisite for L2 learners to attain a native-like command of the language (Schmitt \& Carter, 2004; Meunier, 2012) in spite of great difficulty even for advanced learners (Nesselhauf, 2003; Siyanova \& Schmitt, 2007). Students also find it challenging to put the collocations they know into practice (Schmitt, 2010). As a matter of fact, mere exposure to such terms has failed to facilitate L2 learners' vocabulary repertoire (as demonstrated by Boers \& Lindstromberg, 2009). For students to acquire these idiomatic phrases, Nation (2008) asserted that deliberate vocabulary learning is more beneficial than incidental learning when it comes to the time taken, the amount learned, and the words retained. Peters (2012) elaborated on this idea by proving that L2 learners are unlikely to autonomously recognize or attend to formulaic sequences in a text. Instead, they tend to pay attention to unfamiliar words and ignore lexical phrases consisting entirely of familiar ones (Peters, 2012; Kim, 2016). In that way, a vital first step towards retention, i.e. attention, is missing, according to Schmidt's Noticing Hypothesis (2001).

Furthermore, because of adults' cognitive development, they can have better analytical ability than children. As a result, they can take advantage of explicit instruction and the meta-linguistic explanations of the grammatical rules that underlie chunks (Wray, 2000). Along with structural analysis, extensive chunk practice will help bolster these students' language competence (Ellis, 2002). In a nutshell, adult learners' retention of formulaic sequences is expected to abound if taught explicitly in a formal classroom.

\subsection{Phonology-Based Instruction (PBI)}

Sound effects have been justified for potential mnemonic benefits they bring to learners' attainment of prefabricated chunks (Boers \& Lindstromberg, 2005; Lindstromberg \& Boers, 2008a \& 2008b; Boers, Demecheleer, Coxhead, \& Webb, 2014). Hand counts in English idiom dictionaries revealed that phonological repetition commonly manifests itself $18 \%$ in alliteration (i.e. word-initial consonant reiteration; e.g., time will tell), $2 \%$ in rhyme (i.e. repetition of everything but the front of a word; e.g., high and dry), and about $4 \%$ in assonance (i.e recurrence of vowel sounds; e.g., the mellow wedding bells) (Boers, Deconinck, \& Lindstromberg, 2010). Other cases involve word repetition (e.g. side by $\underline{\text { side) }}$ ) and consonance (i.e. consonants repeated within words, e.g. all mammal named Sam are clammy).

Four major streams of psycholinguistics research regarding phonological similarity identified by Eyckmans, Boers and Lindstromberg (2016) are concerned with (1) learning of short, discrete paired L1 items, (2) short-term recall of various kinds, (3) its effects on implicit priming, and (4) its role in memorization of L1 oral texts. In most paired-associates studies, robust effects have been noticed in the participants' results of recall tests after getting involved in the dictating and sorting tasks. For instance, Lindstromberg and Boers' (2008a) study showed that the alliterative collocations were retrieved significantly better than the controls, and their other research (2008b) on assonant and nonassonant expressions also shared the same result towards the former. Macnamara, Moore and Conway's (2011) experiments, again, corroborated that rhyming words resulted in more effective short-term item recall.

However, Rubin (1995) stipulated that alliterative and rhyming conditions were mnemonic only when participants' attention was drawn to the relevant repetitions. Other studies by Boers, Lindstromberg and Eyckmans (2012 \& 2013) confirmed that awareness-raising component might play an important role in the success of these interventions. Based on these findings, the researcher applied Phonology-Based Instruction (PBI), which provides students with explicit phonological explanations (e.g., "fat chance" assonates, whereas "big/huge chance" do not). Such form-processing proposal has been proved to contribute to learners' better vocabulary memorization.

\subsection{Translation-Based Instruction (TBI)}

On the one hand, corpus studies have pointed out how congruency (i.e. the presence or absence of literal L1 
equivalent) can affect learners' use of L2 collocations (Nesselhauf, 2003; Laufer \& Waldman, 2011; Wolter \& Gyllstad, 2011). Martinez and Murphy (2011), for example, illustrated how L2 learners may misinterpret the meaning of such idiomatic expression as "he's over the hill", based on the meanings of the individual words. In that way, chunks, which highlight the strong patterning in language, cannot often be discerned on a word-by-word basis. In order to make correct meaning attributions, a process of semantic restructuring must occur in which the learner readjusts the semantic knowledge of the word that $\mathrm{s} /$ he possesses to that of the native speaker.

On the other hand, translation approach to vocabulary teaching can be justified in terms of several hypotheses about its effectiveness in L2 learning such as "noticing" (Schmidt, 1994 \& 2001), "pushed output" (Swan \& Lapkin, 1995; De la Fuente, 2002), and "task-induced involvement load" (Laufer \& Hulstjin, 2001; Webb, 2005). Additional justification for incorporating translation tasks into vocabulary learning is provided by earlier research in contrastive semantics, corpus studies and psycholinguistic experiments. The foundation lies in that the acquisition of formulaic language in L1 comes more naturally than in L2 because L1 multiword expressions are encountered, processed and stored holistically (Wray, 2002). Therefore, it has been suggested that new L2 vocabulary is, more often than not, first attributed to learners' L1 interpretation (Hall, 2002; Jiang, 2004). Furthermore, as one of the typical activities in language-focused learning, translation can help students focus on systematic aspects of the language, which is beneficial to their future learning (Nation, 2007). Put together, the employment of translation and contrastive analysis in vocabulary teaching will help increase the depth of processing, the degree of elaboration, the quality of attention and the richness of encoding acted as conditions for vocabulary development.

\subsection{Previous Studies}

Different kinds of intervention, such as using corpora (Chan \& Liou, 2005), raising awareness with typographic enhancement (Peters, 2012), employing high occurrence (Webb, Newton, \& Chang, 2013), stimulating lookups through writing (Laufer, 2011), and facilitating learners' memorization with mnemonic techniques (see more in Boers \& Lindstromberg, 2012), have generated some positive effects on students' acquisition of verb-noun, adjective-noun, and phrasal verb collocations. However, little research is concerned with a mixture of multiword units (i.e. two-word or more strings), different types of phonological repetition (altogether) and conventional teaching strategy like contrastive analysis which capture a more typical picture of a language classroom.

In 2008, Laufer and Girsai examined the influence of three instructional methods on English L2 vocabulary learning: (1) content-oriented tasks, (2) text-based vocabulary tasks, and (3) L1 into L2 and vice versa translation tasks after a reading task. Their findings stipulated that L1 elucidation brought about the best outcome as regards participants' learning of single words as well as collocations. Nevertheless, the third group's outperformance should be taken into further consideration. The translation format included in the post-test for all the three groups might be considered their privileged part of learning procedure over the others.

A recent study by Eyckmans, Boers and Lindstromberg (2016) focused on two proposals to help soak up L2 phrases. 65 EFL learners studied a list of 32 figurative verb-noun phrase expressions accompanied by L1 translations. The control group was only instructed to study the list. One treatment group was additionally instructed to discern phrases whose verb is non-congruent with the L1 translation. The other was required to identify phrases that alliterate. The learning gains suggested that the instruction to look out for alliteration promoted retention, whereas the instruction to compare with L1 did not. However, the pre-test with gapped sentences could not actually gauge students' prior knowledge of the target ones as for some blanks, there might be more than one correct answer. Post-test results, moreover, should be construed with some caution as bilingual glosses were provided for all the groups and mere congruency identification did not reflect the depth of translation.

Although manipulating the occurrence of lexical pharses can enhance the chance of acquisition (Webb, Newton, \& Chang, 2013), according to Szudarski and Carter (2014), other factors may determine the effect of frequency. Given the above considerations, this experimental study will not be based on high levels of lexical occurrence in reading and listening like previous research, but take a closer look at two types of vocabulary guidance - PBI and TBI. As justified by Laufer and Goldstein (2004), the form-meaning relation is the most important element of vocabulary knowledge. The two tasks for post-tests are, therefore, geared towards the form (Identifying) and meaning (and use) of these expressions (Gap-filling). The study in this paper is designed to find out whether more engagement with the form (PBI) and meaning (TBI) of the lexical phrases can help learners durably commit them to memory. 


\section{Methodology}

\subsection{Research Questions}

The study seeks to shed some light on the effectiveness of form and meaning-processing instructions, or to be more specific, PBI and TBI in enhacing students' retention of prefabricated units. For this purpose, the following research questions are addressed for both Immediate and Delayed tests:

1. Will PBI and TBI lead to the Form Recognition of a significantly larger number of lexical items than the control group?

(a) in the case of Repeating phrases;

(b) in the case of Non-repeating phrases.

2. Will PBI and TBI lead to the Form and Meaning Recall of a significantly larger number of lexical items than the control group?

(a) in the case of Repeating phrases;

(b) in the case of Non-repeating phrases.

3. Is there any difference in learning gains across levels of retention (Form Recognition vs Form and Meaning Recall)?

\subsection{Participants}

The participants in this study were 48 Vietnamese EFL students from three intact classes. (Data from students who could not follow the whole procedure were discarded). These English majors were in their second semester of tertiary education (aged 18-20). The number of females was dominant with 36 students (75\%). Their level of proficiency in English was estimated at B1-B2, according to the descriptors of the Common European Framework. They comprised a convenience sample since they were asked to voluntarily take part in the study. Each class was randomly assigned to two treatment groups (PBI and TBI) and a control group (CT) with 17, 15 and 16 students, respectively.

\subsection{Target Items}

A list of 20 polywords was compiled from Collins COBUID Idioms Dictionary. They form two sets of quite balanced sequences in both orthography and congruency: 11 items with repeating patterns and the other 9 without phonological repetition. In Table 1, figures in the third and sixth columns are Google 'exact word' hits (26 March, 2017), given in millions (e.g. $1.7=1.7$ million). It can be seen that, by this measure, all target chunks are of high frequency. To avoid novelty effect, these stimulus phrases consisting only of words among 3000 most frequent word families (according to Nation's base words list calculated from British National Corpus data, see Appendix A) (Heatley, Nation, \& Coxhead, 2002). Choosing target chunks with familiar words in this experiment on learning L2 multiword items is justified by the fact that many lexical phrases consist of high-frequency words (Martinez \& Murphy, 2011). Therefore, acquiring formulaic sequences involves internalizing different combinations of recognizable words.

Table 1. Categorization of target items

\begin{tabular}{llllll}
\hline & Repeating & $\begin{array}{l}\text { Google } \\
\text { result }\end{array}$ & & Non-repeating & $\begin{array}{l}\text { Google } \\
\text { result }\end{array}$ \\
\hline $\begin{array}{l}\text { Assonance } \\
\text { Alliteration }\end{array}$ & Fat chance & 0.427 & Adj + Noun & Wide grin & 0.477 \\
Assonance & Play safe & 0.393 & Compound Noun & Crackpot & 4.31 \\
$\begin{array}{l}\text { Alliteration } \\
\text { Front }\end{array}$ & Pay the piper & 0.382 & Verb + Noun & Hit the sack & 0.176 \\
$\begin{array}{l}\text { Assonance } \\
\text { Back }\end{array}$ & Under the gun & 17.6 & Prep + Noun & & 0.486 \\
$\begin{array}{l}\text { Assonance } \\
\text { Word repetition }\end{array}$ & Under the hammer & 1.72 & & Walk briskly & \\
Word repetition & Eyeball to eyeball & 0.233 & $\ldots$..to... & Hand to mouth & \\
\hline
\end{tabular}




\begin{tabular}{llllll}
\hline $\begin{array}{l}\text { Alliteration } \\
\text { Assonance }\end{array}$ & $\begin{array}{l}\text { Mind over matter } \\
\text { From the cradle to }\end{array}$ & 0.419 & ...over... & Ass over teakettle & 0.122 \\
the grave & From...to... & $\begin{array}{l}\text { From the sublime to the } \\
\text { ridiculous }\end{array}$ \\
$\begin{array}{l}\text { Rhyme } \\
\text { As snug as a bug in } \\
\text { a rug }\end{array}$ & 0.054 & As...as... & $\begin{array}{l}\text { As plain as the nose on } \\
\text { your face }\end{array}$ & 0.052 \\
\hline
\end{tabular}

It has been proved that learners' attention to the context plays an important role in their production of new lexical items. Cohen and Aphek (1980), cited in Carter (2002), indicated that learners of higher proficiency levels are more likely to benefit from learning words in context. Pickering's (1982) experiment on the effectiveness of contextualized versus decontextualized (i.e. translation of isolated words into L1) vocabulary presentation also demonstrated that the former leads to better learning. As a result, in this study, the lexical phrases were presented in a mixed order in sentences with textual clues so that students could infer the meaning of the words without too much diffficulty. For example, the chunk "as snug as a bug in a rug" turns out to be understandable when embedded in the following sentence:

The bedroom in my aunt's house was cold, but after she wrapped me up in four or five blankets, I was as snug as a bug in a rug and ready to go to sleep.

The context helps convey a feeling of being warm and comfortable, which is the meaning of the target item.

\subsection{Pilot Study}

Cook (1996), when commenting on the role of language teachers, referred to the way learners are treated, which may influence their learning motivation. Therefore, the researcher was in charge of teaching the three groups. It might be difficult for one teacher to change teaching style three times. In order to increase the reliability, validity, and practicability of the instruments, a pilot study was carried out in three similar classes (45 minutes each) (Oppenheim, 1992). The intended tests were also tried out and revised with the consultancy of other colleagues to make sure that there is only one correct answer for each question. The sentence below had to be modified because two sensible options could be made:

\section{Stop being such a crackpot / copycat running around in that clown suit!}

It was revised as "Stop being such a crackpot wearing winter clothes in these hot days!" The underlined word is what students had to fill in the blank.

\subsection{The Study Procedure}

The students were told that the whole research is about vocabulary learning but not in detail for fear that it might skew the results. They were also informed that their participation was voluntary, and they were reassured of the anonymity of the results. In the first week, participants took a pre-test to establish the extent of their familiarity with the target expressions. More lexical bundles (30 instead of the intended 20) were listed in random order, and the students were required to tick the phrases that they knew or of which they could guess the meaning. For the checked items, they then provided L1/L2 equivalents to justify their comprehension. The results indicated that most of the chunks, listed separatedly from the context, were unknown to the testees. Even some of their efforts to guess the meaning failed (e.g. They took it for granted that "fat chance" meant more possibility and "under the gun" was the same as in danger).

Two weeks afterwards, one of the three classes was arbitrarily assigned as control group which received conventional instruction on the target words (CT group). Phonology-Based Instruction was adopted for the second class (PBI group). The other class had Translation-Based Instruction (TBI group). The treatment for each group adopted an incidental acquisition design in which the formulaic sequences were acquired mostly through practice and there was no test announcement. The three classes took the same amount of teaching (45 minutes). All the materials were collected after each session to prevent the participants from deliberate learning. Both instructions and tests took place during regular classroom hours. The tests were administered by the classroom teachers and the researcher to ensure fairness.

\subsubsection{CT Group}

The participants in this group did a matching exercise in which they try to infer the meaning of the bold words from the context. After the teacher's feedback, they were given some multiple-choice questions to be clear about the chunks' meanings and usage. One example is as follows:

His salary this month means a hand-to-mouth existence for his family. 
Which of these has the closest meaning to the phrase in boldface?
A. Abundant
B. Sufficient
C. Deficient

Then, they practiced making their own sentences using the target items listed for them.

\subsubsection{PBI Group}

The researcher raised learners' awareness of phonological repetition in everyday language such as nice try, stand

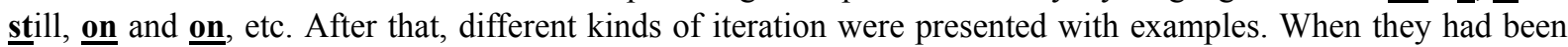
familiar with the concept of alliteration, assonance, rhyme and word repetition, they were asked to sort out the intended chunks into two columns: Repeating (with/without categorizing the types of repetition) and Non-repeating. Their meanings were then inferred from the given contexts. In the last activity, one part of each pattern (both Repeating and Non-repeating) was shown each time for the students to add the missing part, and they made their own sentences using the correct items. For example, fat ?, ? safe, as snug as ? are the hints for fat chance, play safe, as snug as a bug in a rug.

\subsubsection{TBI Group}

The students got involved in two translation tasks and explicit contrastive instruction. In the first task, they were asked to translate the target items in bold font based on their guessing from the contexts. The second task required them to translate the whole L1 sentences into L2 using the phrases they just learned. On each task completion, the instructor checked the answers and provided corrective feedback. The differences between L2 and L1 equivalents were also pointed out. For instance, fat chance can be translated into Vietnamese as vô vong (low possibility), which is used sarcastically instead of the literal meanings of "fat" and "chance". In fact, most of these formulaic sequences cannot be translated word by word (i.e. non-congruent lexis). Therefore, learners need to make connections between L2 and L1 to deal with such complexity. For instance, the phrase "under the hammer" cannot be interpreted as a location, but it calls up an image of an auction. A study by Steinel et al. (2007) demonstrated that idioms which evoke a familiar image result in better retention in terms of L1-L2 paired associates. In addition, the meaning of figurative idioms such as "hit the sack" and "pay the piper" can be motivated by retracing the origin of their literal sense, which has been termed "etymological elaboration" by Boers, Demecheleer and Eyckmans (2004a).

\subsubsection{Testing}

After the treatment, all the learners were unexpectedly tested on the target items (immediate post-test, see Appendix B). In part A (Form Recognition), 10 (with an equal number of Repeating and Non-repeating phrases) of the 20 target items were tested in context. The participants had to judge whether the sentences were written appropriately or not by checking the column and giving corrections if necessary. This test was designed to assess participants' ability to recognize the correct forms of the target chunks, which is considered the crucial first step approaching retention, according to "noticing hypothesis" by Schmidt (2001).

Part B (Form and Meaning Recall) tested the other 10 items (6 Repeating and 4 Non-repeating phrases). Such fill-in exercise is the second highest among 12 exercises analyzed by Nation and Webb (2011) as an effective vocabulary learning technique. Students tried to figure out the most suitable phrases to fill in the blanks (initial letters given). Stengers and Boers (2015) claimed that the first letter cue can prevent students from giving unrelated alternatives. For instance, the cue $\mathrm{f}$ _ should navigate their attention to the target term "fat chance" rather than provide a synonymous one like "no way". The test was completed in 20 minutes, and no feedback was offered at this stage.

After two week's time, the test was used again with a varying order in the presentation of test items (delayed post-test). For the first task, students were given 2 for correct choice of appropriateness, and the marks were divided if precise modification needed (i.e. 1 mark for recognition and 1 mark for revision). A scale by Jones and Haywood (2004) was modified to assess participants' answers. Unlike previous research, the post-tests were scored polytomously, with 2 assigned to a $90 \%$ or more correct answer, 1 to a partly correct $(50 \%)$ and 0 to an incorrect one or a blank. To illustrate, 1 mark will go to answer of "fair chance" instead of "fat chance", or "eye to eye" instead of "eyeball to eyeball". Nearly perfect answers like "as snug as a bug in a plug" receive full marks of 2. The maximum score for each part is 20. As the purpose of the tests was to assess the retention of the formulaic sequences, any grammatical mistakes (e.g. plural forms) could be overlooked if the intended meanings were clear. The same scoring standard was applied for both tests to make sure that data elicited would be 
comparable across tests. Henceforth, the terms "Immediate Test" and "Delayed Test" will be used to refer to these post-tests.

\section{Data Analysis}

Tables 2 and 3 sum up the descriptive statistics of the three groups' performance of the post-tests where the participants were required to identify the correct forms of 10 of the target chunks (Part A). The mean score obtained by TBI group when repeating units are tested immediately is the highest (9.667). The mean score of CT group when dealing with repeating lexis in Part A after two weeks is the lowest (5.25). The percentage is given in brackets to make the two parts comparable as there is discrepancy in the number of Repeating and Non-repeating items. All the scores go down on the Delayed Test fortnightly after the instruction. The score difference in the Immediate Test is not large enough to be statistically significant among the three groups. However, in the Delayed Test the mean scores of PBI and TBI groups are noticeably higher than that of Control group.

Table 2. Form Recognition in Immediate Test

\begin{tabular}{lllllll}
\hline \multirow{2}{*}{ Form Recognition } & \multicolumn{2}{l}{ Control $(\mathrm{N}=16)$} & \multicolumn{3}{l}{ PBI $(\mathrm{N}=17)$} & \multicolumn{2}{l}{ TBI $(\mathrm{N}=15)$} & \\
\cline { 2 - 7 } & Mean & SD & Mean & SD & Mean & SD \\
\hline Repeating & $9.125(91.25 \%)$ & 1.09 & $9.647(96.47 \%)$ & 0.99 & $9.667(96.67 \%)$ & 0.90 \\
Non-repeating & $8.25(82.50 \%)$ & 1.84 & $9.412(94.12 \%)$ & 0.94 & $9.467(94.67 \%)$ & 0.83 \\
\hline
\end{tabular}

Note. $\mathrm{SD}=$ Standard Deviation.

Table 3. Form Recognition in Delayed Test

\begin{tabular}{lllllll}
\hline \multirow{2}{*}{ Form Recognition } & Control $(\mathrm{N}=16)$ & \multicolumn{3}{c}{ PBI $(\mathrm{N}=17)$} & \multicolumn{2}{l}{ TBI $(\mathrm{N}=15)$} \\
\cline { 2 - 7 } & Mean & SD & Mean & SD & Mean & SD \\
\hline Repeating & $5.25(52.50 \%)$ & 2.05 & $7.353(73.53 \%)$ & 1.97 & $8.2(82 \%)$ & 2.46 \\
Non-repeating & $6.625(66.25 \%)$ & 3.07 & $8.471(84.71 \%)$ & 1.59 & $8.533(85.33 \%)$ & 2.64 \\
\hline
\end{tabular}

Note. $\mathrm{SD}=$ Standard Deviation.

Similarly, the descriptive statistics concerning the three groups' test performance in Part B (Form and Meaning Recall) are summarized in Tables 4 and 5. As can be seen from the tables, all the groups performed more poorly in Delayed Test. The mean scores of PBI and TBI groups are more prominent than that of Control group in both Immediate and Delayed tests.

Table 4. Form and Meaning Recall in Immediate Test

\begin{tabular}{lllllll}
\hline \multirow{2}{*}{$\begin{array}{l}\text { Form and Meaning } \\
\text { Recall }\end{array}$} & Control $(\mathrm{N}=16)$ & & PBI $(\mathrm{N}=17)$ & \multicolumn{3}{l}{ TBI $(\mathrm{N}=15)$} \\
\cline { 2 - 7 } & Mean & SD & Mean & SD & Mean & SD \\
\hline Repeating & $7.125(59.38 \%)$ & 3.59 & $9.176(76.47 \%)$ & 2.46 & $8.8(73.33 \%)$ & 2.40 \\
Non-repeating & $4.188(52.44 \%)$ & 2.11 & $6.118(76.59 \%)$ & 2.34 & $5.867(73.40 \%)$ & 2.10 \\
\hline
\end{tabular}

Note. $\mathrm{SD}=$ Standard Deviation.

Table 5. Form and Meaning Recall in Delayed Test

\begin{tabular}{lllllll}
\hline \multirow{2}{*}{$\begin{array}{l}\text { Form and } \\
\text { Meaning Recall }\end{array}$} & Control $(\mathrm{N}=16)$ & \multicolumn{3}{l}{ PBI $(\mathrm{N}=17)$} & \multicolumn{3}{l}{ TBI $(\mathrm{N}=15)$} \\
\cline { 2 - 7 } & Mean & SD & Mean & SD & Mean & SD \\
\hline Repeating & $2.5(20.88 \%)$ & 2.582 & $6(50 \%)$ & 2.5 & $7.933(66.11 \%)$ & 2.789 \\
Non-repeating & $2.313(28.91 \%)$ & 1.957 & $4.471(55.88 \%)$ & 1.972 & $4.6(57.50 \%)$ & 2.293 \\
\hline
\end{tabular}

Note. $\mathrm{SD}=$ Standard Deviation. 
As shown in the tables above, the three groups' performance in the immediate post-test parallels their performance in the delayed post-test, with the PBI and TBI groups obtaining better scores than the no-intervention group. On all the tests, the scores of form detection (Part A) are higher than the corresponding scores of active recall (Part B). This is not surprising as Creating has been placed at the top of the revised Bloom's Taxonomy for the most challenging cognition while Remebering at the bottom (Anderson \& Krathwohl, 2001).

The Shapiro-Wilk Test has been recommended as the suitable choice for testing the data normality of less-than-50 sample (Thode, 2002). As the results imply that the scores in both tests are not normally distributed, Mann-Whitney tests are applied to further examine the differences between each paired sample (e.g. Control vs PBI, PBI vs TBI, Form Recognition vs Form and Meaning Recall, etc.).

\subsection{Form Recognition}

To answer the first research question, the effectiveness of PBI, TBI and CT is compared in terms of Form Recognition in Immediate and Delayed tests. Mann-Whitney test is utilized for each pair of PBI vs CT, TBI vs CT and PBI vs TBI. In Immediate Test, there is no significant difference in Form Recognition of Repeating patterns when all the paired samples are involved. However, concerning Non-repeating words, such ability of TBI group is predominant $(\mathrm{W}=64, \mathrm{p}=0.0267)$.

Delayed Test also witnesses larger chunk recognition by PBI group $(\mathrm{W}=66, \mathrm{p}=0.0109)$ and TBI group $(\mathrm{W}=43$, $\mathrm{p}=0.0017$ ) than the control one as Repeating chunks are taken into consideration. Meanwhile, the identify-the-appropriate condition yields no clear distiction between PBI and TBI groups in learning gains of the Repeating bundles. For the Non-repeating ones, CT group is, again, outperformed by PBI group (W=76, $\mathrm{p}=0.0307$ ) and TBI group $(\mathrm{W}=59, \mathrm{p}=0.0152)$, but there is no considerable disparity between these treatment groups. More often than not, PBI and TBI groups have more learning gains than the controlled, especially when it comes to a fortnight retention. In spite of not much superiority found under two distinct treatments, translation approach tend to be domineering as regards the ability to recognize Non-repeating phrases right after interventions.

\subsection{Form and Meaning Recall}

The second research question concerns the ability to produce correct chunks (Part B). Mann-Whitney test for the Immediate Test indicates that that all the pairs (CT vs PBI, CT vs TBI and PBI vs TBI) are not significantly different as Repeating phrases are counted. Nevertheless, the amount of Non-repeating chunk provision by CT group is much less than PBI's ( $\mathrm{W}=68, \mathrm{p}=0.0136$ ) and TBI's ( $\mathrm{W}=69, \mathrm{p}=0.0448)$.

The same result is noticed in Delayed Test, with the dominance of PBI $(\mathrm{W}=48, \mathrm{p}=0.0011)$ and TBI $(\mathrm{W}=24$, $\mathrm{p}=4.679 \mathrm{e}-5$ ) for Repeating chunks. Surprisingly, TBI members tend to surpass PBI when it comes to chunk production ( $\mathrm{W}=73, \mathrm{p}=0.04022$ ) for Repeating ones. This result goes against the conclusion by Eyckmans, Boers and Lindstromberg (2016) about fewer learning gains under L1 translation treatment. It can be hypothesized that in real learning situations (i.e. when students process different types of chunks altogether), they might pay more attention to meaning, thus fail to focus on lexical composition. In this case, the phonological repetition of the phrases adds no advantage to their chunk retrieval. Although both PBI $(\mathrm{W}=59, \mathrm{p}=0.0048)$ and TBI $(\mathrm{W}=60$, $\mathrm{p}=0.0171$ ) outscore CT group in terms of Non-repeating items, there is no clear distinction between the former groups. In general, the positive effects are more prevailing in Delayed Test, which proves the effectiveness of $\mathrm{PBI}$ and TBI in long-term memory.

\subsection{Form Recognition vs Form and Meaning Recall}

Regarding the last question, Mann-Whitney test for Immediate Test reveals that the amount of L2 uptake differs substantially among participants. For CT group, its members have better ability of recognition than production with their outperformance in Part A in comparison with Part B (W=209, $\mathrm{p}=0.001677)$. The same results are recorded for PBI $(\mathrm{W}=226, \mathrm{p}=0.00425)$ and TBI $(\mathrm{W}=200, \mathrm{p}=0.0001125)$.

In Delayed Test, the predominance of form awareness come as no surprise concerning all the three groups with CT $(\mathrm{W}=229, \mathrm{p}=4.624 \mathrm{e}-5), \mathrm{PBI}(\mathrm{W}=245, \mathrm{p}=0.0002969)$ and TBI $(\mathrm{W}=173, \mathrm{p}=0.01126)$. There is no doubt that form and meaning recall is the harder component with the lowest scores. With the use of most incongruent collocations, the study again confirms Peters' (2015) finding about students' major difficulty in producing such lexical phrases. 


\section{Discussion and Implications}

Throughout the two interventions mentioned above, the participants were provided with opportunities for the achievement of multiple formulaic sequences. The learning, when it occurred, can be said to have been unintentional in the sense that the participants were not explicitly required to internalize the target phrases. Neither were they announced that post-tests would follow.

Form Recognition, as the lowest skill in vocabulary learning, stands out with the highest scores obtained by TBI. However, three groups' equivalence in both post-tests implies that for fundamental level of cognition (i.e. Remembering - Anderson \& Krathwohl, 2001), teaching techniques do not take an important and decisive part in language learners' acquisition of vocabulary. As in Pellicer-Sanchez's (2015) study and other studies related to single words (Web, 2007; Brown, Waring, \& Donkaewbua, 2008), the results also verify that it is more challenging to acquire recall aspects than recognition aspects, and that knowledge of the form of collocations does not seem to be difficult to acquire incidentally under varied interventions.

On the one hand, the research results support the precedents demonstrating the effectiveness of form-processing (PBI) and meaning-processing (TBI) approaches to lexical learning (Lindstromberg \& Boers, 2008a \& 2008b; Laufer \& Girsai, 2008). Parallel trends with the pre-eminence of these two techniques were noticed in high-level activity of chunk production fortnightly after treatments. On the other hand, the present study is different from Eyckmans, Boers and Lindstromberg (2016) in that the pre-test better reflected students' background knowledge, and contrastive analysis was taken to a deeper sense. The intriguing finding on TBI's superiority concerning both Repeating and Non-repeating terms in two cases (Part B of Delayed Test and Part A of Immediate Test, respectively) is in line with the involvement load hypothesis (Laufer \& Hulstijn, 2001), which holds that the participants' engagement in a cognitively demanding task will result in better memorization. Several experiments have also shown that equipping students with the literal origins of idioms does indeed foster retention. The invigoration of the literal meaning of figurative expressions has been proved beneficial to learners' reading comprehension (Boers, 2000) and their appreciation of language-culture connections (Boers, Demecheleer \& Eyckmans, 2004b). As Hulstijn (2001) concluded in a survey of research into vocabulary learning:

It is the nature of information processing which determines retention. The more a learner pays attention to a word's morphological, orthographic, prosodic, semantic and pragmatic features and to intra-word and inter-word relations, the more likely it is that the new lexical information will be retained. (p. 15)

Given the strong effect of learners' L1, one's native language can be attributed to effective L2 chunk learning with an attempt to avoid negative cross-linguistic influence.

In general, time should be spent on high frequency words or words of students' specific needs (Nation, 2005). It has also been suggested that the time given to the language-focused learning activities such as translating and guessing from context should increase at the first stages (Nation, 2007). In this study, the students at low-intermediate level did take more advantage of L1-L2 instruction and contrastive analysis. Recent work on deliberate vocabulary learning also highlights the benefits of the minimization of error risks over practice based mostly on teachers' corrective feedback (Warmington \& Hitch, 2014). Therefore, activities of raising awareness like form recognition can be put more emphasis on.

There is no doubt that classroom time is too limited to explicitly teach a vast number of formulaic word strings. Teachers' responsibility is to draw students' attention to lexical phrases of high frequency and relevance to their purposes. According to Boers and Lindstromberg (as cited in Littlemore, 2009), although there are different ways to motivate chunk learning, it is unpredictable how effective they are for our students. After all, classroom activities should diverge as to provide learners with strategies that enable them to learn the bulk of vocabulary autonomously (Nation, 2001).

\section{Conclusion}

The study investigated the impact of two treatments PBI and TBI on EFL students' chunk learning. Through the post-tests addressing two levels of retention Recognition and Recall, it has been demonstrated that such interventions led to more learning gains in the acquisition of formulaic sequences. Therefore, in pedagogic practice, teachers may combine both of these instructions: specify contrasts/similarities with L1 and also (if applicable) point out phonological similarity in order to intensify students' ability to retrieve form and meaning of the lexical phrases.

This article, nevertheless, reports on a small-scale study in one specific context, lasting for five weeks. The influence of the "etymological elaboration" (Boers, Demecheleer \& Eyckmans, 2004a) on contrastive analysis of L1 and L2 equivalents has yet to be well-addressed in this study. It is also necessary to investigate reasons why 
certain vocabulary may cause difficulties to students and to identify more variables that have an impact on learners' memory such as vocabulary size and word length (Peters, 2015). Further research might examine students' vocabulary reproduction in speaking and writing over a greater period of time and in a variety of contexts.

As Boers and Lindstromberg (2009) and Webb et al. (2013) asserted, the occurrence of chunks in most written and spoken discourse is not sufficient for noticing, let alone incidental learning. Given the growing awareness of their significance and students' slow competence (Forsberg, 2010; Laufer \& Waldman, 2011), it has, therefore, been recommended that textbooks include exercises focusing on lexical phrases, such as matching and cloze tasks where learners' attention is directed to form and meaning of authentic patterns.

\section{References}

Anderson, L. W., \& Krathwohl, D. R. (Eds.). (2001). A taxonomy for learning, teaching and assessing: A revision of Bloom's Taxonomy of educational objectives: Complete edition. New York: Longman.

Boers, F. (2000). Enhancing metaphoric awareness is specialised reading. English for Specific Purposes, 19(2), 137-147. https://doi.org/10.1016/s0889-4906(98)00017-9

Boers, F., Deconinck, J., \& Lindstromberg, S. (2010). Choosing motivated chunks for teaching. In S. De Knop, F. Boers, A. De Rycker (Eds.), Fostering language teaching efficiency through cognitive linguistics (pp. 239-256). https://doi.org/10.1515/9783110245837.239

Boers, F., Demecheleer, M., Coxhead, A., \& Webb, S. (2014). Gauging the effects of exercises on verb-noun collocations. Language Teaching Research, 18, 54-74. https://doi.org/10.1177/1362168813505389

Boers, F., Demecheleer, M., \& Eyckmans, J. (2004a). Etymological elaboration as a strategy for learning figurative idioms. In P. Bogaards \& B. Laufer (Eds.), Vocabulary in a second language: Selection, acquisition and testing (pp. 53-78). https://doi.org/10.1075/11lt.10.07boe

Boers, F., Demecheleer, M., \& Eyckmans, J. (2004b). Cultural variation as a variable in comprehending and remembering figurative idioms. European Journal of English Studies, 8, 375-388. https://doi.org/10.1080/1382557042000277449

Boers, F., \& Lindstromberg, S. (2005). Finding ways to make phrase learning feasible: the mnemonic effect of alliteration. System, 33, 225-238. https://doi.org/10.1016/j.system.2004.12.007

Boers, F., \& Lindstromberg, S. (2009). Optimizing a lexical approach to instructed language acquisition. Basingstoke: Palgrave Macmillan. https://doi.org/10.1057/9780230245006

Boers, F., \& Lindstromberg, S. (2012). Experimental and intervention studies on formulaic sequences in a second language. Annual Review of Applied Linguistics, 32, 83-110. https://doi.org/10.1017/s0267190512000050

Boers, F., Lindstromberg, S., \& Eyckmans, J. (2012). Are alliterative word combinations comparatively aasy to remember for adult learners? RELC Journal, 43(1), 127-135. https://doi.org/10.1177/0033688212439997

Boers, F., Lindstromberg, S., \& Eyckmans, J. (2013). Is alliteration mnemonic without awareness-raising? Language Awareness. https://doi.org/10.1080/09658416.2013.774008

Brown, R., Waring, R., \& Donkaewbua, S. (2008). Incidental vocabulary acquisition from reading, reading-while-listening, and listening. Reading in a Foreign Language, 20, 136-163. https://doi.org/10.1080/17501229.2016.1203328

Carter, R. (2002). Vocabulary: Applied linguistics perspectives (2nd ed.). London/New York: Routledge.

Chan, T. P., \& Liou, H. C. (2005). Effects of web-based concordancing instruction on EFL students' learning of verb-noun collocations. Computer Assisted Language Learning, 18, 231-251. https://doi.org/10.1080/09588220500185769

Cohen, L., Manion, L., \& Morrison, K. (2000). Research methods in education (5th ed.). London: Routledge Falmer. https://doi.org/10.4324/9780203224342

Cook, V. (1996). Second language learning and teaching. https://doi.org/10.1177/026765839300900304

Craik, F. I. M., \& Lockhart, R. S. (1972). Levels of processing: A framework for memory research. Journal of Verbal Learning and Verbal Behavior, 11, 671-684. https://doi.org/10.1016/s0022-5371(72)80001-x

De la Fuente, M. J. (2002). Negotiation and oral acquisition of L2 vocabulary: The roles of input and output in the receptive and productive acquisition of words. Studies in Second Language Acquisition, 24, 81-112. 
https://doi.org/10.1017/s0272263102001043

Ellis, N. (2002). Frequency effects in language processing. Studies in Second Language Acquisition, 24, 143-188. https://doi.org/10.1017/s0272263102002024

Eyckmans, J., Boers, F., \& Lindstromberg, S. (2016). The impact of imposing processing strategies on L2 learners' deliberate study of lexical phrases. System, 56, 127-139. https://doi.org/10.1016/j.system.2015.12.001

Forsberg, F. (2010). Using conventional sequences in L2 French. IRAL, 48(1), 25-51. https://doi.org/10.1515/iral.2010.002

Hall, C. J. (2002). The automatic cognate form assumption: Evidence for the parasitic model of vocabulary acquisition. International Review of Applied Linguistics, 40, 69-87. https://doi.org/10.1515/iral.2002.008

Heatley, A., Nation, I.S.P., \& Coxhead, A. (2002). Range and frequency programs. Retrieved January 9, 2017, from http://www.victoria.ac.nz/lals/about/staff/paul-nation.

Hill, J. (2000). Revising priorities: from grammatical failure to collocational success. In M. Lewis (Ed.), Teaching collocation: Further developments in the lexical approach (pp. 47-69). London: Heinle, Cengage Learning.

Hulstijn, J. H. (2001). Intentional and incidental second-language vocabulary learning: A reappraisal of elaboration, rehearsal and automaticity. In P. Robinson (Ed.), Cognition and second language instruction (pp. 258-286). https://doi.org/10.1017/cbo9781139524780.011

Jiang, N. (2004). Semantic transfer and development in adult L2 vocabulary acquisition. In P. Bogaards, \& B. Laufer (Eds.), Vocabulary in a second language: Selection, acquisition, and testing (pp. 101-126). https://doi.org/10.1075/11lt.10.09jia

Jones, M., \& Haywood, S. (2004). Facilitating the acquisition of formulaic sequences: An exploratory study in an EAP context. In N. Schmitt (Ed.), Formulaic sequences (pp. 269-300). https://doi.org/10.1075/11lt.9.14jon

Kim, C. (2016). L2 learners' recognition of unfamiliar idioms composed of familiar words. Language Awareness, 25(1-2), 89-109. https://doi.org/10.1080/09658416.2015.1122025

Laufer, B. (2011). The contribution of dictionary use to the production and retention of collocations in a second language. International Journal of Lexicography, 24, 29-49. https://doi.org/10.1093/ijl/ecq039

Laufer, B., \& Girsai, N. (2008). Form-focused instruction in second language vocabulary learning: A case for contrastive analysis and translation. Applied Linguistics, 29(4), 694-716. https://doi.org/10.1093/applin/amn018

Laufer, B., \& Goldstein, Z. (2004). Testing vocabulary knowledge: Size, strength, and computer adaptiveness. Language Learning, 54, 469-523. https://doi.org/10.1111/j.0023-8333.2004.00260.x

Laufer, B., \& Hulstijn, J. (2001). Incidental vocabulary acquisition in a second language: The construct of task-induced involvement. Applied Linguistics, 22, 1-26. https://doi.org/10.1093/applin/22.1.1

Laufer, B., \& Waldman, T. (2011). Verb-noun collocations in second language writing: corpus analysis of learners' English. Language Learning, 61, 647-672. https://doi.org/10.1111/j.1467-9922.2010.00621.x

Lewis, M. (Ed.) (2000). Teaching collocation. https://doi.org/10.1093/elt/55.4.413

Lindstromberg, S., \& Boers, F. (2008a). Teaching chunks of language: From noticing to remembering. Rum, Austria: Helbling Languages.

Lindstromberg, S., \& Boers, F. (2008b). Phonemic repetition and the learning of lexical chunks: The power of assonance. System, 36, 423-436. https://doi.org/10.1016/j.system.2008.01.002

Littlemore, J. (2009). Applying cognitive linguistics to second language learning and teaching. https://doi.org/10.1057/9780230245259_10

Macnamara, B., Moore, A., \& Conway, A. (2011). Phonological similarity effects in simple and complex span tasks. Memory and Cognition, 39(7), 1174-1186. https://doi.org/10.3758/s13421-011-0100-5

Martinez, R., \& Murphy, V. A. (2011). Effect of frequency and idiomaticity on second language reading comprehension. TESOL Quarterly, 45, 267-290. https://doi.org/10.5054/tq.2011.247708

Meunier, F. (2012). Formulaic language and language teaching. Annual Review of Applied Linguistics, 32, 


\section{1-129. https://doi.org/10.1017/s0267190512000128}

Nation, I. S. P. (2001). Learning vocabulary in another language. https://doi.org/10.14198/raei.2002.15.18-2

Nation, I. S. P. (2005). Teaching vocabulary. Asian EFL Journal, 7(3), 47-54.

Nation, I. S. P. (2007). The four strands. Innovation in Language Learning and Teaching, 1(1), 2-13. https://doi.org/10.2167/illt039.0

Nation, I. S. P. (2008). Teaching vocabulary: Strategies and techniques. Boston, MA: Heinle Cengage Learning.

Nation, I. S. P., \& Webb, S. (2011). Researching and analyzing vocabulary. https://doi.org/10.1177/1362168813493852

Nattinger, J. R., \& DeCarrico, J. S. (1992). Lexical phrases and language teaching. https://doi.org/10.7202/001902ar

Nesselhauf, N. (2003). The use of collocations by advanced learners of English and some implications for teaching. Applied Linguistics, 24(2), 223-242. https://doi.org/10.1093/applin/24.2.223

Oppenheim, A. N. (1992). Questionnaire design, interviewing and attitude measurement. https://doi.org/10.2307/3172892

Pellicer-Sanchez, A. (2015). Learning L2 collocations incidentally from reading. Language Teaching Research. https://doi.org/10.1177/1362168815618428

Peters, E. (2012). Learning German formulaic sequences: The effect of two attention drawing techniques. Language Learning Journal, 40, 65-79. https://doi.org/10.1080/09571736.2012.658224

Peters, E. (2015). The learning burden of collocations: The role of interlexical and intralexical factors. Language Teaching Research. https://doi.org/10.1177/1362168814568131

Pickering, M. (1982). Context-free and context-dependent vocabulary learning: An experiment. System, 10(1), 79-83. https://doi.org/10.1016/0346-251x(81)90070-1

Rubin, D. (1995). Memory in oral traditions: The cognitive psychology of epic, ballads, and counting-out rhymes. https://doi.org/10.1037/e412922005-008

Schmidt, R. (1994). Deconstructing consciousness in search of useful definitions for applied linguistics. Special Issue of AILA Review, 11, 11-26.

Schmidt, R. (2001). Attention. In P. Robinson (Ed.), Cognition and second language instruction (pp. 3-32). https://doi.org/10.1017/cbo9781139524780.003

Schmitt, N. (Ed.) (2004). Formulaic sequences: Acquisition, processing and use. https://doi.org/10.1093/applin/ami018

Schmitt, N. (2010). Researching vocabulary: A vocabulary research manual. https://doi.org/10.1177/1362168813510433

Schmitt, N., \& R. Carter (2004). Formulaic sequences in action: an introduction. In N. Schmitt (Ed.), Formulaic Sequences (pp.1-22). https://doi.org/10.1075/1llt.9.02sch

Siyanova, A., \& Schmitt, N. (2007). Native and nonnative use of multiword versus one-word verbs. International Review of Applied Linguistics in Language Teaching, 45(2), 119-139.

https://doi.org/10.1515/iral.2007.005

Smith, M. S. (1991). Speaking to many minds: On the relevance of different types of language information for the L2 learner. Second Language Research, 7(2), 118-132. https://doi.org/10.1177/026765839100700204

Steinel, M. P., Hulstijn, J. H., \& Steinel, W. (2007). Second language idiom learning in a paired-associate paradigm: Effects of direction of learning, direction of testing, idiom imageability, and idiom transparency. Studies in Second Language Acquisition, 29, 449-484. https://doi.org/10.1017/s0272263107070271

Stengers, H., \& Boers, F. (2015). Exercises on collocations: A comparison of trial-and-error and exemplar-guided

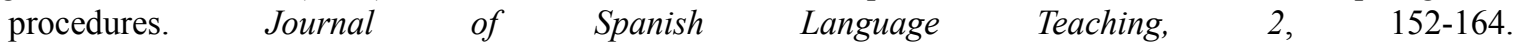
https://doi.org/10.1080/23247797.2015.1104030

Szudarski, P., \& Carter, R. (2014). The role of input flood and input enhancement in EFL learners' acquisition of collocations. International Journal of Applied Linguistics. https://doi.org/10.1111/ijal.12092

Swain, M., \& Lapkin, S. (1995). Problems in output and the cognitive processes they generate: A step towards 
second language learning. Applied Linguistics, 16, 371-391. https://doi.org/10.1093/applin/16.3.371

Thode, H. J. (2002). Testing for normality. New York: Marcel Dekker. https://doi.org/10.1201/9780203910894

Tremblay, A., Derwing, B., Libben, G., \& Westbury, C. (2011). Processing advantages of lexical bundles: Evidence from self-paced reading and sentence recall tasks. Language Learning, 61(2), 569-613. https://doi.org/10.1111/j.1467-9922.2010.00622.x

Warmington, M., \& Hitch, G. J. (2014). Enhancing the learning of new words using an errorless learning procedure: Evidence from typical adults. Memory, 22, 582-594. https://doi.org/10.1080/09658211.2013.807841

Watanabe, Y. (1997). Input, intake, and retention. Studies in Second Language Acquisition, 19, 287-307. https://doi.org/10.1017/s027226319700301x

Webb, S. (2005). Receptive and productive vocabulary learning: The effects of reading and writing on word knowledge. Studies in Second Language Acquisition, 27, 33-52. https://doi.org/10.1017/s0272263105050023

Webb, S. (2007). The effects of repetition on vocabulary knowledge. Applied Linguistics, 28, 46-65. https://doi.org/10.1093/applin/aml048

Webb, S., Newton, J., \& Chang, A. (2013). Incidental learning of collocation. Language Learning, 63, 91-120. https://doi.org/10.1111/j.1467-9922.2012.00729.x

Wood, D. (Ed.) (2010). Perspectives on formulaic language: Acquisition and communication. https://doi.org/10.1111/j.1473-4192.2010.00279.x

Wolter, B., \& Gyllstad, H. (2011). Collocational links in the L2 mental lexicon and the influence of L1 intralexical knowledge. Applied Linguistics, 32, 430-449. https://doi.org/10.1093/applin/amr011

Wray, A. (2000). Formulaic sequences in second language teaching: Principle and practice. Applied Linguistics, 21, 463-489. https://doi.org/10.1093/applin/21.4.463

Wray, A. (2002). Formulaic language and the lexicon. Cambridge: Cambridge University Press. https://doi.org/10.1017/cbo9780511519772

$\begin{array}{llll}\begin{array}{l}\text { Appendix A } \\ \text { Word range }\end{array} & & & \\ \text { WORD LIST } & \text { TOKENS/\% } & \text { TYPES/\% } & \text { FAMILIES } \\ \text { One } & 42 / 61.76 & 23 / 48.94 & 23 \\ \text { Two } & 9 / 13.24 & 8 / 17.02 & 8 \\ \text { Three } & 2 / 2.94 & 2 / 4.26 & 2 \\ \text { Not in the lists } & 15 / 22.06 & 14 / 29.79 & ? ? ? ? ? \\ \text { Total } & 68 & 47 & 33\end{array}$

\section{Appendix B}

\section{Immediate Test}

A. Identify if these sentences are written appropriately (A) or not (I) by checking the columns. Make corrections if necessary.

\begin{tabular}{|c|c|c|c|}
\hline & $\overline{\mathbf{A}}$ & I & Corrections \\
\hline $\begin{array}{l}\text { 1. His face broke into a wide laugh when he saw her coming towards him. } \\
\text { 2. That Justin guy is wearing the same shoes as him. What a copy lad! } \\
\text { 3. When Brad opened the door, she walked briskly in to avoid the cold. } \\
\text { 4. After fooling around for most of the semester, now he has to stay the piper } \\
\text { and study over vacation. }\end{array}$ & & & \\
\hline
\end{tabular}


5. The paintings must come below the hammer if we're to pay the mortgage. 6. The two companies are neck and neck in the competition to win over customers.

7. My father earned very little, so we lived from hand till mouth.

8. Margaret was determined to go to the wedding even on crutches. That's mind over fact.

9. The performances at the festival ranged from the sublime to the ridiculous.

10. There's no doubt that he likes her. It's as plain as the mole on your face.

\section{B. Fill in the blanks with the most suitable phrases (initial letters given)}

11. "I'll invite her to the Prom."-"You, with her? F... !."

12. Stop being such a c.... wearing winter clothes in these hot days!

13. Let's p by getting a backup in case the announced speaker gets sick.

14. When I h. I often read for a few minutes, and then turn off the light.

15. The reporter was $\mathbf{u}$ for that article on taxes to be in the news.

16. The USA is using the c.... approach with North Korea in order to close down the nuclear weapons plants.

17. In the first debate, our candidate is going $\mathbf{e}$ with his opponent.

18. My poor sister just went a on the ice out there. I hope she isn't hurt!

19. Free medical care might not be with us f. as we once hoped.

20. During the blizzard, we had plenty of firewood and stayed in the cottage a

\section{Copyrights}

Copyright for this article is retained by the author(s), with first publication rights granted to the journal.

This is an open-access article distributed under the terms and conditions of the Creative Commons Attribution license (http://creativecommons.org/licenses/by/4.0/). 